\title{
A STATUS ASSESSMENT OF PERKINSIOSIS, BONAMIOSIS, AND MATEILIOSIS IN COMMERCIAL MARINE BIVALVES FROM SOUTHERN BRAZIL
}

\author{
SIMONE SÜHNEL, ${ }^{1,2 *}$ STEWART C. JOHNSON, ${ }^{3}$ HELEN J. GURNEY-SMITH, ${ }^{2}$ \\ CELENE DA S. IVACHUK, ${ }^{1}$ ANA L. C. SCHAEFER, ${ }^{1}$ CATHERINE A. THOMSON, ${ }^{2}$ \\ MARIA LUIZA T. MACIEL, ${ }^{4}$ MAURÍCIO L. MARTINS, ${ }^{1}$ RAQUEL ARANGUREN, \\ ANTONIO FIGUERAS ${ }^{\mathbf{5}}$ AND AIME RACHEL M. MAGALHÃES ${ }^{\mathbf{1}}$ \\ ${ }^{1}$ Nucleus for Aquatic Pathology Studies, Center of Agrarian Sciences, Federal University of Santa \\ Catarina, Rodovia Admar Gonzaga, 1346, 88040-900, Florianópolis, Santa Catarina, Brazil; ${ }^{2}$ Centre for \\ Shellfish Research, Vancouver Island University, 900 Fifth Street, Nanaimo, British Columbia, V9R 5S5 \\ Canada; ${ }^{3}$ Pacific Biological Station, Fisheries and Oceans Canada, 3190 Hammond Bay Road, Nanaimo, \\ British Columbia, V9T 6N7, Canada; ${ }^{4}$ Ministry of Agriculture, Avenida Loureiro da Silva, 515, 90010- \\ 420, Porto Alegre, Rio Grande do Sul, Brazil; ${ }^{5}$ Spanish National Reference Laboratory for Mollusc \\ Diseases, Instituto de Investigaciones Marinas, Consejo Superior de Investigaciones Científicas (CSIC), \\ Eduardo Cabello, 6, 36208 Vigo, Spain
}

\begin{abstract}
The protozoans Perkinsus marinus, Perkinsus olseni, Bonamia ostreae, Bonamia exitiosa, and Marteilia refringens are responsible for some of the most detrimental diseases in the production of cultivated shellfish worldwide and are classified as notifiable diseases by the World Organization for Animal Health (OIE). This study examined the general health status of wild and cultured bivalves from southern Brazil and included diagnostic tests for the presence of Perkinsus sp., Bonamia sp., and Marteilia sp. Cultured bivalves included the mangrove oyster Crassostrea gasar (syn. Crassostrea brasiliana), the brown mussel Perna perna, the lion's paw scallop Nodipecten nodosus, and wing pearl oyster Pteria hirundo. The mangrove oyster Crassostrea rhizophorae and the carib pointed venus clam Anomalocardia brasiliana (syn. Anomalocardia flexuosa) were collected from wild populations. A variety of parasitic or commensal organisms were detected by histology including Ancistrocoma-like and Spenophrya-like organisms; Bucephalus genus, Nematopsis sp., Steinhausia sp., and Tylocephalum sp.; unidentified trematode; unknown protozoan and metazoans; and an amoeba parasite. Hemocytic infiltration was most commonly associated with parasitized animals. Histological, culture and molecular diagnostic tests did not find any evidence of the presence of OIE-listed pathogens or related species in this study. Although the current survey did not identify any pathogens or diseases of concern, it provides baseline health assessment data for these species against which any future disease developments or significant changes in population health can be compared. These data are also valuable with respect to the development and implementation of public policies related to aquatic animal health.
\end{abstract}

KEY WORDS: OIE diseases, shellfish, pathology

\section{INTRODUCTION}

Historically bivalve molluses such as the zigzag scallop Euvola (Pecten) ziczac (Linnaeus, 1758), carib pointed venus clam Anomalocardia brasiliana (Gmelin, 1791) [syn. Anomalocardia flexuosa (Linnaeus, 1767)], brown mussel Perna perna (Linnaeus, 1758), and the mangrove oysters Crassostrea rhizophorae (Guilding, 1828) and Crassostrea gasar (Adanson, 1757) [syn. Crassostrea brasiliana (Lamark, 1819)] have been important in Brazil as both food and income sources for many coastal communities. Over the past $20 \mathrm{y}$, the demand for bivalves has increased, which coupled with declining wild harvests has increased interest in bivalve aquaculture, including the introduction and culture of nonnative species such as the Japanese oyster Crassostrea gigas (Thunberg, 1793) (Poli 2004).

Bivalve culture in Brazil began in the 1970s, and since 1988 activities have increased to a scale that provides an important alternative source of income to small enterprise fisherman, who often operate as members of associations or cooperatives. Brazilian shellfish culture is dominated by the culture of the brown mussel, followed by the Japanese oyster. There is additional production of native species including the lion's

*Corresponding author. E-mail: ssuhnel@gmail.com DOI: $10.2983 / 035.035 .0116$ paw scallop Nodipecten nodosus (Linnaeus, 1758) and the mangrove oysters Crassostrea rhizophorae and Crassostrea gasar (FAO 2004). Bivalves are primarily grown in the southern states of Brazil, with Santa Catarina responsible for more than $95 \%$ of the total mollusc production (EPAGRI 2014).

Relatively little is known about the health status, pathogens, and parasites of bivalve populations in Brazil (Table 1). The World Organization for Animal Health (OIE)-listed diseases of bivalve molluscs are those which are caused by Bonamia ostreae, Bonamia exitiosa, Marteilia refringens, Perkinsus marinus, and Perkinsus olseni (OIE 2011). Species of Perkinsus have been reported from oysters in the states of Ceará, Paraíba, Bahia, and Sergipe (Sabry et al. 2009, 2013, Brandão et al. 2013b, Da Silva et al. 2013, Queiroga et al. 2013, Da Silva et al. 2014, Da Silva et al. 2015, Queiroga et al. 2015) and in clams from Ceará (Ferreira et al. 2015). Two of these cases represent reports of an OIE-listed Perkinsus parasite. Da Silva et al. (2013) reported the presence of $P$. marinus based on rDNA region internal transcribed spacer and large subunit sequences in oysters Crassostrea rhizophorae, and Da Silva et al. (2014) and Queiroga et al. (2015) reported $P$. marinus and $P$. olseni by molecular analysis in Crassostrea gasar. Both oyster species were collected from Paraiba, northern Brazil. None of the OIE-listed bivalve diseases have been reported from other states in Brazil. 


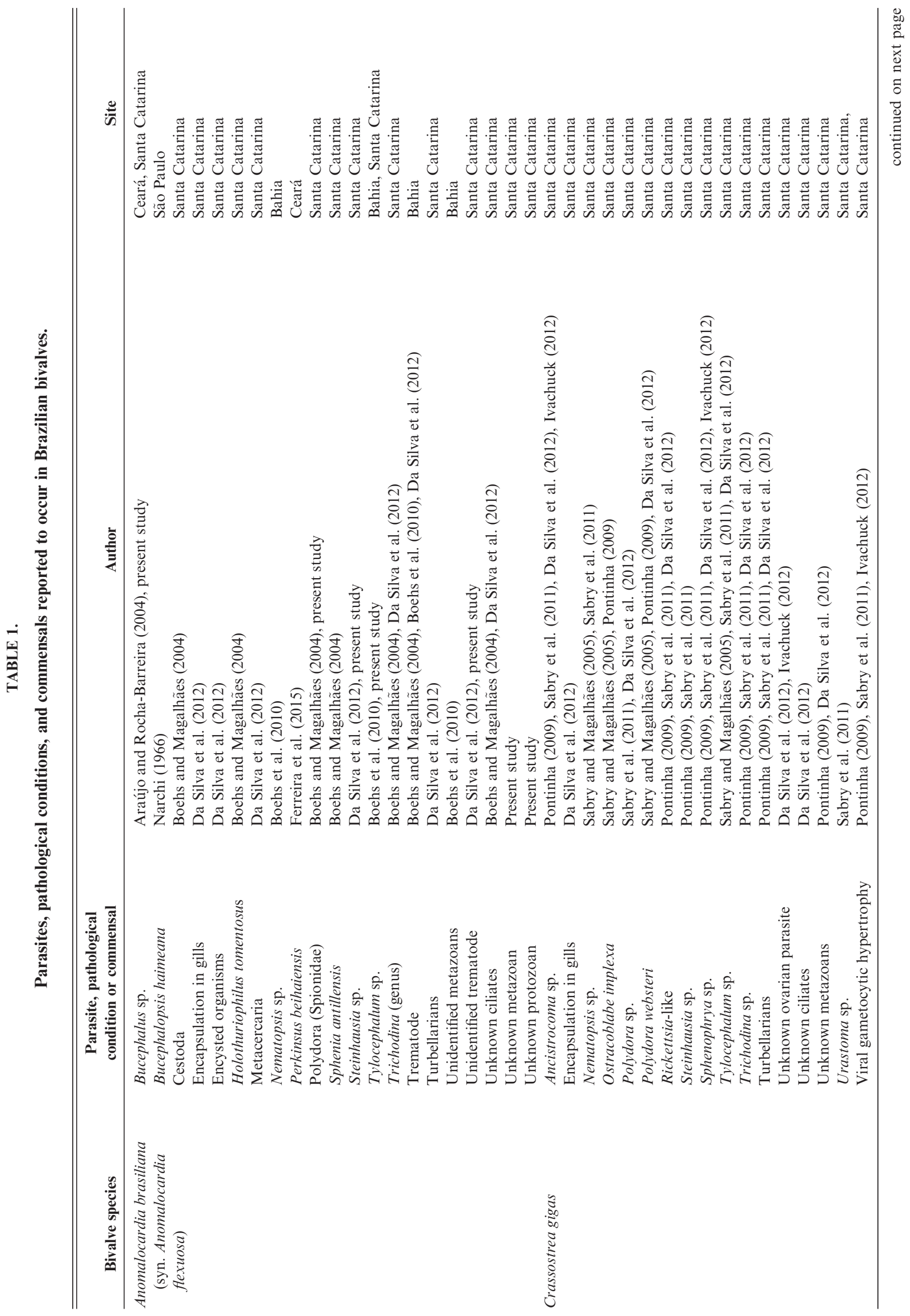


Evaluation of OIE Diseases in Brazilian Molluscs

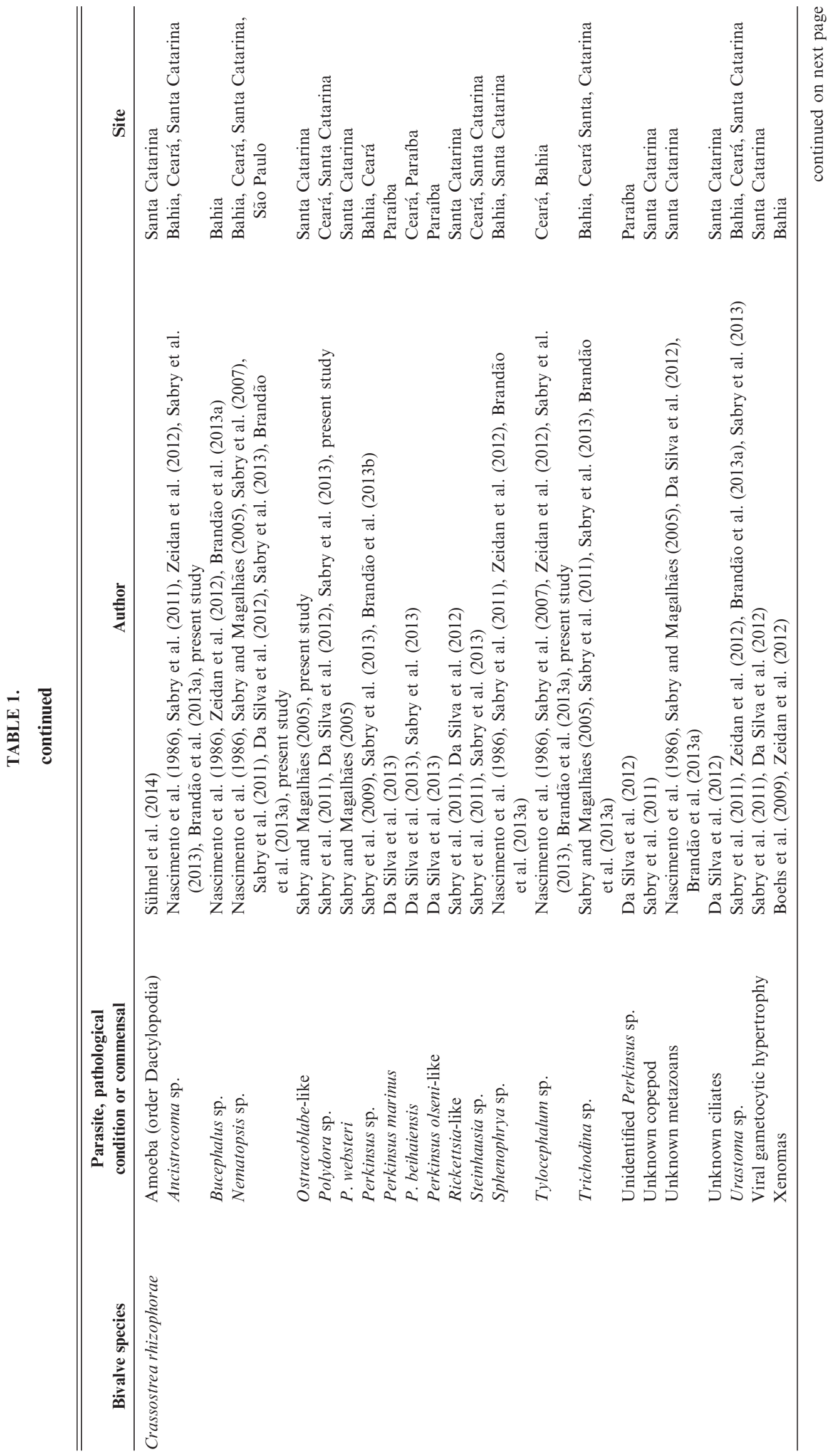




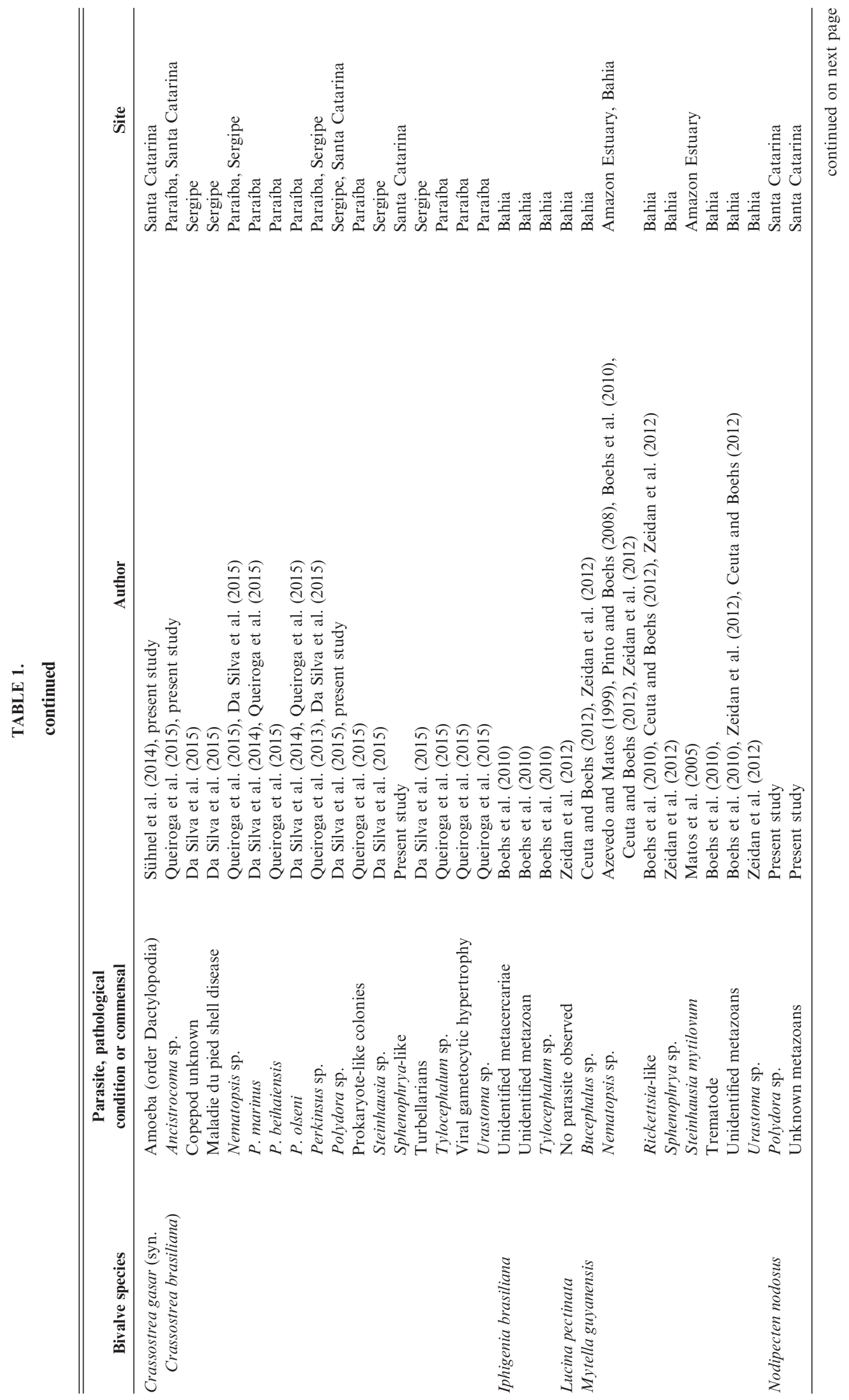


Evaluation of OIE Diseases in Brazilian Molluscs

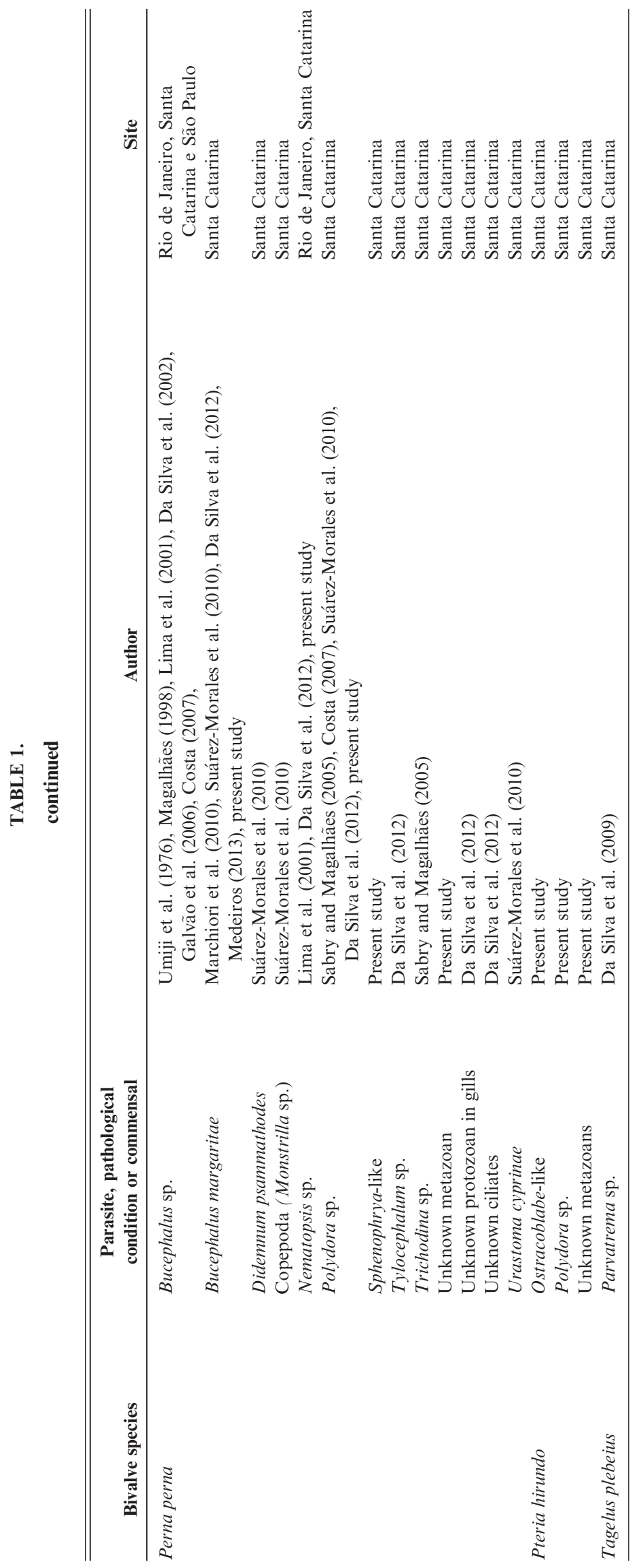


This study examined wild and cultured populations of economically important bivalves from the state of Santa Catarina, southern Brazil, for general health using histology techniques and for the presence of pathogens responsible for OIE-listed bivalve diseases using culture and molecular methods. Improved understanding of the baseline health status of Brazilian bivalve populations is important and is essential to ensure the continued successful development of the industry and to support the development of appropriate regulatory policies.

\section{MATERIALS AND METHODS}

\section{Collection Sites and Processing}

A total of 870 bivalves were collected in winter 2009 and summer 2010 from four locations in Santa Catarina, southern Brazil. Wild oysters, Crassostrea rhizophorae, were randomly selected from one rocky shore site (approximately $100 \mathrm{~m}^{2}$ ) at Praia da Ponta do Sambaqui, Florianópolis $\left(27^{\circ} 29^{\prime} 26.49^{\prime \prime} \mathrm{S}\right.$ and $48^{\circ} 32^{\prime} 17.88^{\prime \prime} \mathrm{W}$ ). This site is approximately $500 \mathrm{~m}$ from areas where molluscs are cultured. Carib pointed venus clams Anomalocardia brasiliana were collected randomly from one site (approximately $200 \mathrm{~m}^{2}$ ) within the Reserva Marinha Extrativista do Pirajubaé (Marine Extractive Reserve of Pirajubaé), Florianópolis $\left(27^{\circ} 29^{\prime} 18.8^{\prime \prime} \mathrm{S}\right.$ and $\left.48^{\circ} 32^{\prime} 12.9^{\prime \prime} \mathrm{W}\right)$. This reserve, managed by the Instituto Brasileiro do Meio Ambiente e dos Recursos Naturais Renováveis, is one of the largest clam harvesting areas in Santa Catarina.

Samples of brown mussels Perna perna, mangrove oysters Crassostrea gasar, and winged pearl oysters Pteria hirundo (Linnaeus, 1758) were obtained from culture systems within the experimental area of the Federal University of Santa Catarina,

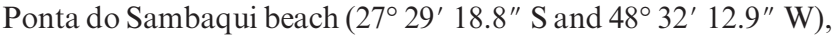
Florianópolis. This is the most important area of oyster seed production in southern Brazil. Samples of lantern net-cultured scallops Nodipecten nodosus were collected from the experimental area of Empresa de Pesquisa Agropecuária e Extensão Rural de Santa Catarina ( $27^{\circ} 12^{\prime} 5.39^{\prime \prime} \mathrm{S}$ and $\left.48^{\circ} 30^{\prime} 47.7^{\prime \prime} \mathrm{W}\right)$. This northern location is an important shellfish production area, especially for $P$. perna.

Live animals were transported on ice to the Nucleus for Aquatic Pathology Study laboratory in the Federal University of Santa Catarina for necropsy and tissue sampling. At necropsy, shell lengths were obtained, and each animal was examined for gross tissue lesions or other signs of disease. Tissue samples of the bivalves for diagnostic testing were removed using sterile techniques and treated as described below.

The number and size of each species examined is provided in Table 2. In the case of wild-collected Crassostrea rhizophorae and Anomalocardia brasiliana, subsamples of 40 of the 150 individuals examined for gross signs of disease were randomly selected for analysis by hemolymph smears, tissue imprints, and histology (Table 2). A random subset of animals previously sampled for diagnostic testing was also sampled for molecular analysis.

\section{Microscopic Analysis}

\section{Ray's Fluid Thioglycollate Culture Method}

Rectum and gill tissues were dissected into Falcon tubes containing Ray's fluid thioglycollate culture media (Ray 1954,
1966), to which antibiotics $(500 \mathrm{U} / \mathrm{ml}$ penicillin, $500 \mathrm{U} / \mathrm{ml}$ streptomycin) and an antifungal (nystatin: 10,000 U/ml) were added. Tubes were incubated at room temperature $\left(24.0^{\circ} \mathrm{C} \pm\right.$ $1.5^{\circ} \mathrm{C}$ ) for 5 days in the dark. After incubation, the tissues were removed, macerated onto glass slides, and stained with Lugol's solution. Slides were examined first at $5 \times$ objective, then at $100 \times$ objective for the detection of hypnospores of Perkinsus spp. as recommended by the OIE (OIE 2011).

\section{Tissue Imprints}

Small pieces $(2 \times 2 \mathrm{~mm})$ of heart, gonad, gill, and digestive gland were dried on absorbent paper, and four imprints of each tissue were made onto glass slides. Slides were air-dried, fixed in methanol (1 $\mathrm{min})$, stained with Giemsa (2 min), washed in distilled water ( $1 \mathrm{~min})$, air-dried, and then mounted with a coverslip using Evermount. Slides were examined first at $40 \times$ objective and then under oil immersion at $100 \times$ objective for the detection of Bonamia spp. and Marteilia spp. (OIE 2011).

\section{Hemolymph Smears}

Hemolymph samples were obtained from the adductor muscle using 21-gauge (for scallops, mussels, pearl oysters, and true oysters) and 26-gauge needles (for clams) attached to 1-mL sterile syringes. Samples were smeared onto glass slides to form a monolayer, air-dried, and stained with Giemsa as described in section Tissue Imprints. Slides were examined first at $10 \times$, then at $40 \times$ objective, and finally under oil immersion at $100 \times$ objective for the presence of Bonamia spp. and Perkinsus spp. (OIE 2011).

\section{Histopathology}

To obtain a representative sampling of the visceral mass (which includes gills, gonad, digestive gland, foot, and mantle), a single transverse cross-section (approximately $5 \mathrm{~mm}$ thick) was excised from each individual following the procedures outlined in the works of Howard and Smith (1983) and Howard et al. (2004). Tissues were placed in cassettes, fixed for $48 \mathrm{~h}$ in Davidson's fixative (Shaw \& Battle 1957), dehydrated, and embedded in paraffin. Then $5-\mu \mathrm{m}$ sections were mounted on slides, deparaffinized, and stained with hematoxylin and eosin. Slides were examined using light microscopy at 10-100× objective for the presence of Bonamia spp., Perkinsus spp., and Marteilia spp. (OIE 2011), as well as signs of disease and/or other pathogens and parasites. The percent prevalence of each parasite was calculated as the number of parasitized animals divided by the total number of each bivalve species multiplied by 100 for each sampling (Bush et al. 1997).

\section{Molecular Analysis: Polymerase Chain Reaction}

For the detection of Bonamia spp. and Marteilia spp. by polymerase chain reaction (PCR), a small piece of gill and digestive gland tissue was preserved in $95 \%$ undenatured ethanol. Molecular diagnostic testing was conducted on 60 individuals each of Perna perna, Crassostrea gasar, Nodipecten nodosus, and Anomalocaria brasiliana (Table 2).

For each individual a pool consisting of approximately equal amounts of gill and digestive gland was created, and DNA was extracted using DNeasy Blood \& Tissue Kit (QIAGEN) following the manufacturer's instructions. Deoxyribose nucleic 
Evaluation of OIE Diseases in Brazilian Molluscs

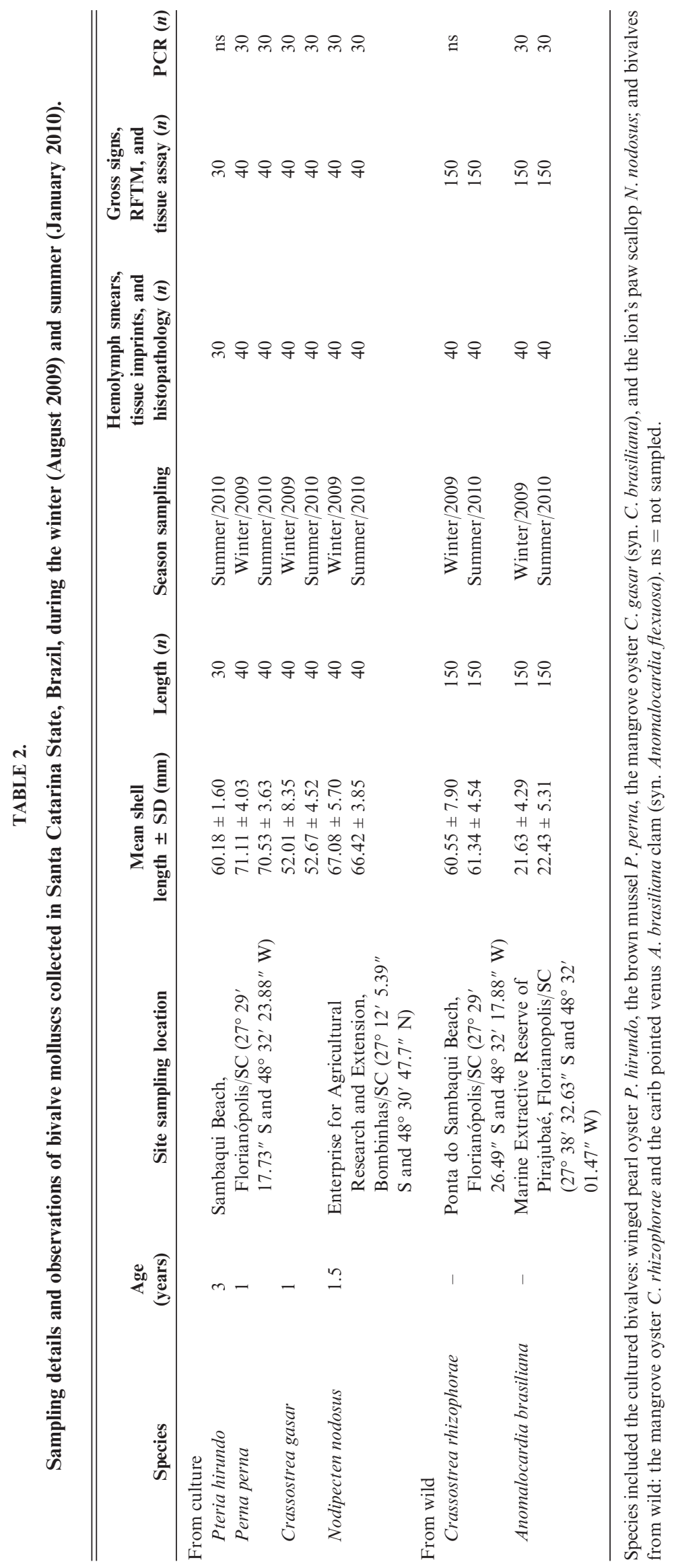


acid concentration and purity was measured using a NanoVue spectrophotometer.

For the Marteilia refringens analysis, the PCR was performed according to the protocol by Le Roux et al. (2001) and OIE (2011), using the primer set M2A 5'-CCG-CAC-ACGTTC-TTC-ACT-CC-3' and M3AS 5'-CTC-GCG-AGT-TTCGAC-AGA-CG-3'. Each PCR reaction consisted of $48 \mu \mathrm{l}$ of PCR SuperMix (Applied Biosystems) and $2 \mu \mathrm{l}$ of DNA at a concentration of $100 \mathrm{ng} / \mu \mathrm{l}$. Amplification was carried out in a Mastercycler Gradient (Eppendorf) under the following conditions: initial denaturation at $94^{\circ} \mathrm{C}$ for $10 \mathrm{~min}$, followed by 30 amplification cycles at $94^{\circ} \mathrm{C}$ for $1 \mathrm{~min}, 55^{\circ} \mathrm{C}$ for $1 \mathrm{~min}$, and $72^{\circ} \mathrm{C}$ for $1 \mathrm{~min}$, with a final elongation step at $72^{\circ} \mathrm{C}$ for $10 \mathrm{~min}$. The PCR products were run on $1.5 \%$ agarose gels at $100 \mathrm{~V}$ for $40 \mathrm{~min}$, and the presence or absence of amplified DNA of the expected product size $(412 \mathrm{bp})$ was assessed by comparison with products obtained for positive controls (plasmid ligations of Marteilia type M DNA supplied by Isabelle Arzul, Laboratory for Mollusc Diseases and OIE Reference Laboratory for bonamiosis and marteiliosis, IFREMER, France).

For the detection of Bonamia spp., the PCR was performed according to the protocol by Cochennec et al. (2000) and OIE (2011), using the primer set BO 5'-CAT-TTA-ATT-GGTCGG-GCC-GC-3' and BOAS 5'-CTG-ATC-GTC-TTCGAT-CCC-CC-3'. The PCR reaction consisted of $48 \mu \mathrm{l}$ of PCR SuperMix and $2 \mu \mathrm{l}$ of DNA at a concentration of $100 \mathrm{ng} / \mu \mathrm{l}$. Amplification was carried as follows: initial denaturation at $94^{\circ} \mathrm{C}$ for $5 \mathrm{~min}$, followed by 30 amplification cycles at $94^{\circ} \mathrm{C}$ for $1 \mathrm{~min}, 55^{\circ} \mathrm{C}$ for $1 \mathrm{~min}$, and $72^{\circ} \mathrm{C}$ for $1 \mathrm{~min}$, followed by a final elongation at $72^{\circ} \mathrm{C}$ for $10 \mathrm{~min}$. The PCR products were run on a $1.5 \%$ agarose gel at $100 \mathrm{~V}$ for $40 \mathrm{~min}$, and the presence or absence of amplified DNA of the expected product size (300 bp) was assessed by comparison with products obtained from the amplification of positive controls for Bonamia exitiosa and Bonamia ostreae (plasmid ligations of parasite DNA from each species again supplied as above by Isabelle Arzul).

\section{RESULTS}

The animals collected from aquaculture sites ranged in age from 1 to 3 years. The precise age of the wild collected bivalves were unknown, but their size and level of gonad development suggested that they were all adults (Table 2). During necropsy, orange lesions on the gonad of the brown mussel, Perna perna, were observed in $25 \%$ of the animals collected in both winter and summer. These lesions were not observed in the other studied species.

Ostracoblabe-like condition was observed in the summer 2010 in cultured oysters Crassostrea rhizophorae and Pteria hirundo, in 1 and $5 \%$ of samples respectively (Table 3 ). There was no evidence of these infections impeding valve closure and there was no damage evident in adjacent tissues.

Polychaetes, genus Polydora (Spionidae), were present in all of the bivalve species that were examined, occurring at highest prevalence in Crassostrea rhizophorae and Crassostrea gasar in both winter and summer samples. Polychaetes were also found albeit at lower prevalences in Perna perna, Nodipecten nodosus and Anomalocardia brasiliana in both seasons, and only occurred in Pteria hirundo in low numbers in the summer season (Table 3). Some individuals with the highest infestations also had yellow abscesses in the gonadal tissue and the adductor muscle in association with the mud blisters.

No other shell diseases were observed.

\section{Microscopic Observations and PCR}

A high prevalence of haemocytic infiltration (HI) was observed in many of the species examined (Table 3). The highest prevalences occurred in Anomalocardia brasiliana, Crassostrea rhizophorae, Crassostrea gasar and Perna perna with $28 \%$ to $98 \%$ of the animals displaying this condition. In A. brasiliana haemocytic infiltrations were associated with Bucephalus infections, which were commonly found in the digestive gland, gonad and mantle tissues. These were also associated with unidentified trematode infection in the connective tissues and with an unknown protozoan infection in the gill of $A$. brasiliana. In $P$. perna the haemocytic infiltration was again associated with Bucephalus infections, and was observed in $20 \%$ of the heavily infected animals (i.e., those with the parasite in more than three different organs) in the winter and $70 \%$ of the heavy infected animals in the summer.

During the analysis two ovarian parasites were observed an amoeba parasite (Figure 1A) and a microsporidian (Figure $1 \mathrm{~B})$. The amoeba was found in the oocyte and gonad connective tissues of both oyster species, Crassostrea rhizophorae and Crassostrea gasar. Full descriptions of this parasite can be found in Sühnel et al. (2014). Da Silva et al. (2012) and Ivachuck (2013) observed a similar parasite described as unknown ovarian parasite in the oyster Crassostrea gigas, from the same region (Sambaquí Beach, Florianópolis). The highest prevalence of this amoeba was observed in winter samples of C. gasar (Table 3). This amoeba parasite may affect the oocyte viability, impacting reproduction performance, although more analysis would be necessary to fully elucidate the impact of this parasite on the reproductive viability of the host. The other ovarian parasite was a Steinhausia-like microsporidian (Figure 1B), which was observed at low prevalence in summer Anomalocardia brasiliana clam samples, where it infected the oocyte cytoplasm (Table 3). No host reaction was observed in the infected animals. Sporocysts (diameter: $14.91 \pm$ $0.08 \mu \mathrm{m})$ contained spores at different development stages.

The bucephalid infecting the mussel Perna perna was identified as Bucephalus margaritae (Figure 1C). The species from Anomalocardia brasiliana could only be identified to genus as Bucephalus sp. (Figure 1D). In both cases the parasite was observed as sporocyst and cercariae stages, according to the description in Marchiori et al. (2010). In both summer and winter samples prevalence was low in $P$. perna mussel samples but higher in $A$. brasiliana clams. $50 \%$ of individuals in winter $P$. perna samples had heavy infections (parasite found in more than three organs; i.e. gill, gonad and digestive gland). All summer samples had heavy infections. This was not the case for A. brasiliana where $100 \%$ of the infected animals showed lowintensity infections in the connective tissue in the winter and summer. Whilst $100 \%$ of infections were associated with characteristic orange lesions in $P$. perna, such lesions were not observed in A. brasiliana necropsies.

An unidentified trematode (Figure 1E) was observed in the connective tissue of the clam Anomalocardia brasiliana.

Nematopsis sp. (Apicomplexa: Eugregarinida) (Figure 1F) were present in $80 \%$ and $75 \%$ of Crassostrea rhizophorae, 
TABLE 3.

Percent prevalence of pathology and parasites in bivalves collected from Santa Catarina State, southern Brazil, during the winter 2009 and summer 2010.

\begin{tabular}{|c|c|c|c|c|c|c|c|c|c|c|c|}
\hline \multirow{3}{*}{$\begin{array}{l}\text { Pathological condition } \\
\text { and organisms }\end{array}$} & \multicolumn{5}{|c|}{ Winter/2009 } & \multicolumn{6}{|c|}{ Summer/2010 } \\
\hline & \multicolumn{3}{|c|}{ Cultured bivalves } & \multicolumn{2}{|c|}{$\begin{array}{l}\text { Wild-collected } \\
\text { bivalves }\end{array}$} & \multicolumn{4}{|c|}{ Cultured bivalves } & \multicolumn{2}{|c|}{$\begin{array}{c}\text { Wild-collected } \\
\text { bivalves }\end{array}$} \\
\hline & P.p. & C.g. & $N . n$ & C.r. & A.b. & P.h. & P.p. & C.g. & $N . n$ & C.r. & A.b. \\
\hline $\mathrm{HI}$ & 42.5 & 2.5 & 2.5 & 27.5 & 97.5 & 5.0 & 67.5 & 42.5 & 2.5 & 32.5 & 57.5 \\
\hline Amoeba & 0 & 45.0 & 0 & 0 & 0 & 0 & 0 & 2.5 & 0 & 10.0 & 0 \\
\hline Ancistrocoma-like & 0 & 2.5 & 0 & 0 & 0 & 0 & 0 & 0 & 0 & 2.5 & 0 \\
\hline Bucephalus sp. & 0 & 0 & 0 & 0 & 97.5 & 0 & 0 & 0 & 0 & 0 & 57.5 \\
\hline Bucephalus margaritae & 25.0 & 0 & 0 & 0 & 0 & 0 & 25.0 & 0 & 0 & 0 & 0 \\
\hline Nematopsis sp. & 0 & 0 & 0 & 80.0 & 0 & 0 & 0 & 0 & 0 & 75.0 & 0 \\
\hline Ostracoblabe-like & 0 & 0 & 0 & 0 & 0 & 5.0 & 0 & 0 & 0 & 1.0 & 0 \\
\hline Polydora sp. & 12.5 & 75.0 & 5.0 & 84.0 & 0.3 & 33.3 & 22.5 & 97.5 & 10.5 & 96.6 & 0.5 \\
\hline Sphenophrya-like & $2.5^{*}$ & $5.0^{*}$ & 0 & 0 & 0 & 0 & 0 & $22.5^{*}$ & 0 & 0 & 0 \\
\hline Steinhausia sp. & 0 & 0 & 0 & 0 & 0 & 0 & 0 & 0 & 0 & 0 & 2.5 \\
\hline Tylocephalum sp. & 0 & 0 & 0 & 15.0 & 2.5 & 0 & 0 & 0 & 0 & 0 & 0 \\
\hline Unidentified trematode & 0 & 0 & 0 & 0 & 2.5 & 0 & 0 & 0 & 0 & 0 & 2.5 \\
\hline Unknown metazoan & $2.5^{*}$ & 0 & 0 & 0 & $10.0^{*}$ & 0 & 0 & 0 & 0 & 0 & $2.5^{*}$ \\
\hline Unknown metazoans & 5.0 & 0 & $7.5^{*}$ & 0 & 0 & $7.5^{*}$ & 7.5 & 0 & $15.0^{*}$ & 0 & 0 \\
\hline Unknown protozoan & 0 & 0 & 0 & 0 & $2.5^{*}$ & 0 & 0 & 0 & 0 & 0 & 0 \\
\hline
\end{tabular}

Cultured bivalves included brown mussels Perna perna (P.p.), mangrove oysters Crassostrea gasar (C.g.) (syn. brasiliana), lion's paw scallops Nodipecten nodosus (N.n.), and wing pearl oysters Pteria hirundo (P.h.). Wild-collected bivalves were mangrove oysters Crassostrea rhizophorae (C.r.) and carib pointed venus Anomalocardia brasiliana clams (A.b.) (syn. A. flexuosa).

* Parasite or commensal first time reported for the species.

collected in the winter and summer samples respectively (Table 3), and was most commonly found in digestive glands, with occurrence to a lesser extent in gonad, gill and mantle tissues. No other bivalve species examined in the present study was infected by Nematopsis sp.

Ciliates (genus Sphenophrya, Figure 1G) were found at low infection rates in gills of summer Perna perna samples, and in winter and summer samples of Crassostrea gasar. Another ciliate species, genus Ancistrocoma (Figure 1H), was found at low prevalence in the digestive gland of Crassostrea rhizophorae (summer) and C. gasar (winter, Table 3 ).

Platyhelminth infections (Tylocephalum sp.; Figure 1I; mean \pm standard deviation sizes $97.66 \pm 0.04 \mu \mathrm{m}$ by $80.34 \pm 0.08 \mu \mathrm{m}$ ) were observed in the connective tissues of Anomalocardia brasiliana and Crassostrea rhizophorae winter samples, with a higher prevalence seen in the latter (Table 3).

An unknown metazoan (Figure 1J) was observed in the gill filaments of Anomalocardia brasiliana in an encapsulated form, with higher winter prevalence than in summer samples. This parasite was also observed in low levels in the gill filaments of Perna perna winter samples (Table 3), but at a different development stage, with the diameter ranging from 135.36 to $190.15 \mu \mathrm{m}$.

Three other unidentified metazoans were observed at low prevalence in different species in this study. In Pteria hirundo an unknown metazoan $(99.47 \pm 2.49 \mu \mathrm{m}$ diameter, Figure $1 \mathrm{~L})$ was found encapsulated in the digestive gland. In Perna perna, an unknown metazoan $(93.00 \pm 8.11 \mu \mathrm{m}$ diameter; Figure $1 \mathrm{M})$ was observed encapsulated in the connective tissue of the mussel. An unknown metazoan (Figure $1 \mathrm{~N}$ ) in the lumen of the intestine and stomach of Nodipecten nodosus was found.
RFTM assays (Perkinsus spp.), tissue imprints (Bonamia spp. and Marteilia spp.), haemolymph smears (Bonamia spp. and Perkinsus spp.) and PCR analysis (Bonamia exitiosa, Bonamia ostreae and Marteilia refringens) showed all negative results for the studied bivalves.

\section{DISCUSSION}

Ostracoblabe-like condition observed in the present study showed similar characteristics described by Bower (2001), where nacre covered bumps which protrude from the shell into the adductor muscle are a typical sign of infection with the fungus Ostracoblabe implexa. Other shell diseases observed in the present study, Polydora, was observed by Sabry and Magalhães (2005) causing mud blisters in the bivalve shells, with $100 \%$ of the infected animals, and are known to be associated with polychaete infections.

A high prevalence of haemocytic infiltration (HI) was observed in many of the species examined (Table 3 ). The highest prevalences occurred in Anomalocardia brasiliana, Crassostrea rhizophorae, Crassostrea gasar and Perna perna with 28\% to $98 \%$ of the animals displaying this condition. The high haemocytic infiltration observed in C. rhizophorae and C. gasar could be related to gonad parasites infection as observed by Sühnel et al. (2014). In P. perna, infiltration was linked to unknown metazoans, but was also observed in unparasitized mussels, and may be related to reproductive physiology or to an unidentified potential agent.

Ovarian parasites observed in the present study as similar those observed by Da Silva et al. (2012) and Ivachuck (2012), described as unknown ovarian parasite in the oyster Crassostrea 

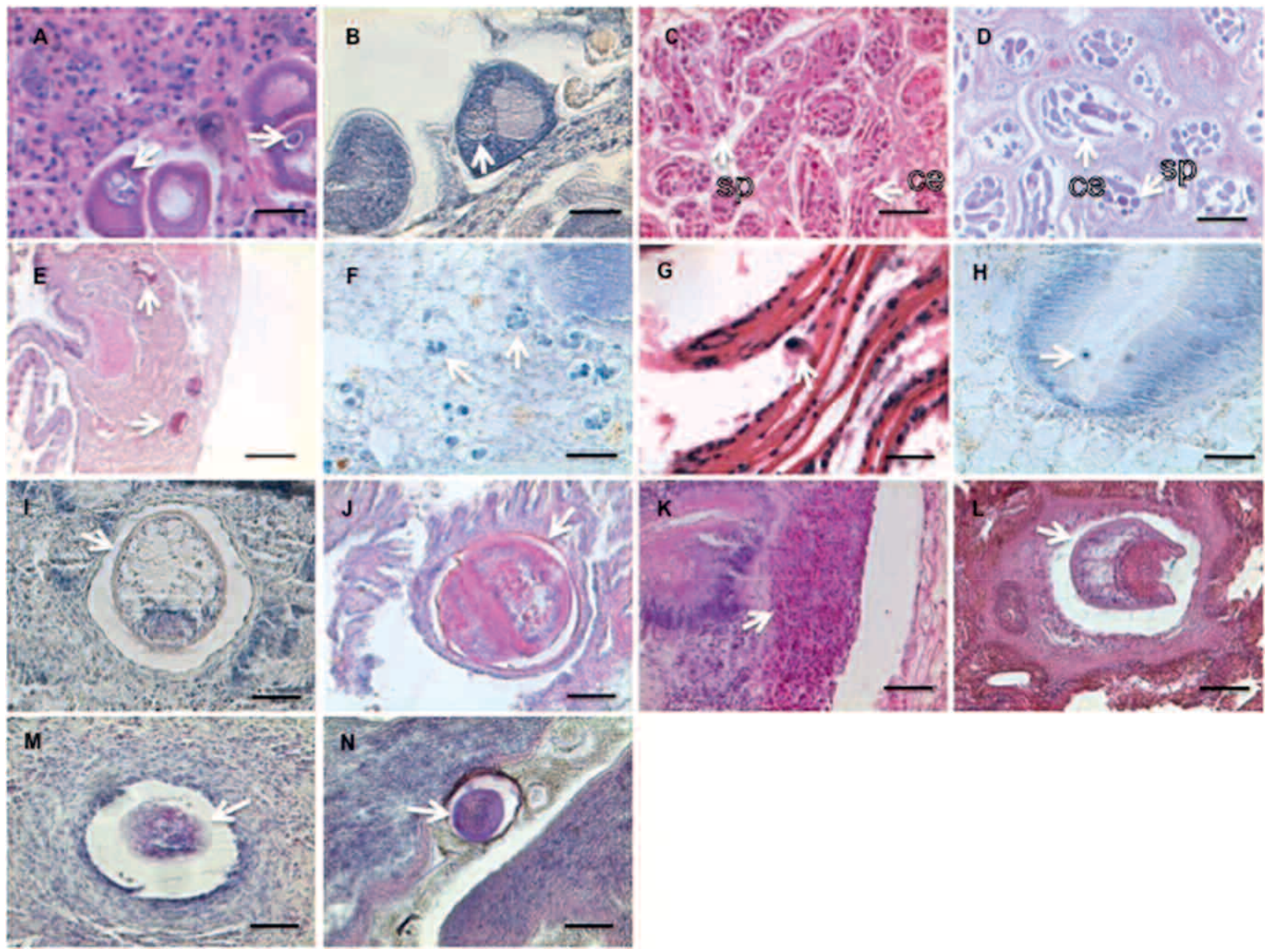

Figure 1. Histological section (hematoxylin and eosin stain) of bivalves molluses from Santa Catarina, Brazil: (A) unknown ovarian parasite in the oocyte cytoplasm of the oyster Crassostrea gasar, (B) Steinhausia sp. sporocyst in the oocyte cytoplasm of the clam Anomalocardia brasiliana, (C) Bucephalus margaritae infecting the gonad tissue of the mussel Perna perna, (D) Bucephalus sp. infecting the gonad tissue of the clam A. brasiliana, (E) unidentified trematode infecting the connective tissue of the clam A. brasiliana, (F) Nematopsis sp. oocysts in the connective tissue of the oyster Crassostrea rhizophorae, (G) Sphenophrya-like ciliate in the gill of the oyster C.gasar, (H) ciliate Ancistrocoma sp. in the digestive gland of the oyster C.rhizophorae, (I) Tylocephalum sp. in the connective tissue of the clam A. brasiliana, (J) unknown metazoan infecting the gill filament of the clam $A$. brasiliana, (K) unknown protozoan infecting the connective tissue of the clam $A$. brasiliana, (L) unknown metazoan infecting the digestive gland of the pearl oyster Pteria hirundo, (M) unknown metazoan infecting connective tissue of the mussel $P$. perna, and $(\mathrm{N})$ unknown metazoan infecting the digestive gland of the scallop Nodipecten nodosus. Scale bar in A and B: $200 \mu \mathrm{m}(100 \times$ objective); scale bar in C, D, E, H, I, J, K, L, M, and N: $50 \mu \mathrm{m}(40 \times$ objective); scale bar in F: $50 \mu \mathrm{m}$ (10× objective); scale bar in G: $20 \mu \mathrm{m}$ (100× objective); sp: sporocyst; ce: cercariae; arrows: parasites.

gigas, from the same region (Sambaquí Beach, Florianópolis). The other ovarian parasite, Steinhausia-like, has been observed in Brazil in the oysters C. gigas (Pontinha 2009, Sabry et al. 2011) and Crassostrea rhizophorea (Sabry et al. 2011), in the mussel Mytella guyanensis (Matos et al. 2005), and in the clam Anomalocardia brasiliana (Da Silva et al. 2012).

As bucephalids are often highly specific for their host species (Lauckner 1983), more studies are required to determine which species is associated with Anomalocardia brasiliana infections. Buchephalosis has been reported in the A. brasiliana clam in Brazil (Narchi 1966, Araújo \& RochaBarreira 2004, Boehs \& Magalhães 2004, Boehs et al. 2010, Da Silva et al. 2012), as well as in the mussel Perna perna (Umiji et al. 1976, Magalhães 1998, Lima et al. 2001, Da Silva et al. 2002, Galvão et al. 2006, Costa 2007, Marchiori et al.
2010, Da Silva et al. 2012). In this study bucephalosis was not observed in oysters (Crassostrea rhizophorae, Crassostrea gasar, Pteria hirundo) or the scallop (Nodipecten nodosus) (Table 3), but it has been reported in C. rhizophorae in more northerly sample sites by Nascimento et al. 1986 (São Paulo State). Bucephalid parasites have also been found in two commercially important fishery species, Mytella guyanensis (Boehs et al. 2010, Ceuta \& Boehs 2012) and Lucina pectinata (Oliveira 2008) in Bahia. Bucephalids are known to cause parasitic castration in molluscs (Shelley 1988), which can affect the reproductive capacity of individuals in naturally recruiting wild populations.

The unidentified trematode observed in Anomalocardia brasiliana as similar those registered by Da Silva et al. (2012), with encysted phases in the kidney and mantle of $A$. brasiliana. 
Histological signs of infection with Nematopsis sp., as registered in the present study, include oocysts with an irregular outline that are bound by a single thickened membrane (Padovan et al. 2003). These protozoa use bivalves as intermediate hosts for gametogonic and sporogonic life stages and complete their life cycle in the digestive tract of crustaceans. In the present study, there was little evidence of histopathological changes in any infected tissues, even for animals with more intense haemocytic infiltration. The infection of Crassostrea rhizophorae with Nematopsis sp. is not unusual as previous reports have found oocysts of this species ranging from $60 \%$ to $100 \%$ (Sabry et al. 2007) in a Jaguaribe River Estuary population (mainly in mantle and gill tissues), and 14\% in subepithelial gill tissues in a northeastern population in Recife (Azevedo et al. 2005).

This is the first time that these Sphenophrya-like ciliate have been reported in the Crassostrea gasar oyster. While ciliates are commensal organisms, feeding from suspended particles in the gill and mantle of bivalves in this case (Kinne 1983), their presence in high abundance or during periods of environmental and/or physiological stress can cause damage to the host organism (Lauckner 1983).

An unknown metazoan (Fig. 1J) was observed in the gill filaments of Anomalocardia brasiliana in an encapsulated form, with higher winter prevalance than in summer samples. This parasite was also observed in low levels in the gill filaments of Perna perna winter samples (Table 3), but at a different development stage, with the diameter ranging from 135.36 to $190.15 \mu \mathrm{m}$.

The unknown metazoan infecting Anomalocardia brasiliana observed, is morphologically identified as a copepod, but other authors studying gastropod gill lamellae suggest a similar encapsulated organism may be a metacercarian cyst (De Vico \& Carella 2012). This is the first time that this unknown metazoan in $A$. brasiliana has been observed parasitizing the bivalves $A$. brasiliana and Perna perna. This study is also the first reported case of this unknown protozoan in the connective tissue and gill filaments of $A$. brasiliana, although a similar unidentified protozoan has been reported in the gill filaments of the mussel P. perna by Da Silva et al. (2012). Also the unknown metazoan observed in Nodipecten nodosus is the first known occurrence.

In general the parasites and commensal species found in this study have been previously reported in bivalves from Brazil and elsewhere, and are generally considered benign (Bower et al. 1992, Magalhães \& Ferreira 2006). The exceptions for this are the ovarian parasites and Bucephalus infections, which are known to affect the bivalve reproduction. More research into the unknown parasites observed in this study is needed to identify possible host relationships, using specific techniques such as in situ hybridization, molecular analysis and electron microscopy.

About OIE diseases, other studies have examined bivalves collected in the vicinity of the sample sites for the presence of Perkinsus species. Crassostrea rhizophorae collected from Sambaqui Beach and Ribeirão da Ilha, Florianópolis (SC) were reported to be negative for the parasites Perkinsus spp. and a Perkinsus beihaiensis-like species using the RFTM assay, whereas oysters collected in the estuary of the River Package, Fortaleza (CE), in northeastern Brazil tested positive (Sabry et al. 2009, Sabry et al. 2013). Also in Bahia, Brandão et al. (2013b) confirmed the presence of Perkinsus spp., by RFTM and PCR assays, which had infected the rectum, intestine and stomach of C. rhizophorae oysters. Da Silva et al. (2012) did not find Perkinsus spp. using RFTM assays in a range of the present studied bivalve species from Santa Catarina (Perna perna, C. rhizophorae, Crassostrea gigas and Anomalocardia brasiliana). In addition, these authors also examined two specimens of Crassostrea gigas for the presence of Marteilioides chungmuensis, both of which tested negative for this pathogen. Based on the histological and tissue imprint examinations, no Marteilioides refringens or Marteilia-related species were present in the bivalves tested. Furthermore the $M$. refringens-specific PCR results were all negative. Although species of Marteilia have been reported from a wide variety of bivalves and geographical locations, this genus has never been reported in South American waters (Table 1; Berthe et al. 2004).

The present study found no evidence of Bonamia species in the samples following examination of haemolymph samples, tissue imprints and histological sections. PCR results using a primer set specific for Bonamia ostreae and Bonamia exitiosa were also all negative. The OIE lists all susceptible hosts of $B$. exitiosa and $B$. ostreae as all species within the genus Ostrea. Bonamiosis has been reported in Ostrea chilensis from New Zealand (Dinamani et al. 1987, Doonan et al. 1994, Hine and Jones 1994, Hine 1996), in Ostrea angasi from Australia (Corbeil et al. 2006) Ostrea stentina from Tunisia (Hill et al. 2010) and in Ostrea edulis from Europe (Abollo et al. 2008, Carrasco et al. 2012). Also, bonamiosis has been reported in the genus Crassostrea, where Crassostrea ariakensis was infected by Bonamia exitiosa (Dungan et al. 2012). Although Bonamia have not been reported in Brazilian bivalves, it is important to note that oysters within the genus Ostrea have not been examined in Brazil. The puelche oyster, Ostrea puelchana, is found in the waters of southern Brazil, has been reported to be a host of Bonamia spp. based on collections made in Northern Argentina (Kroeck \& Montes 2005, Kroeck 2010). Bonamia spp. has also been reported from the cultured Chilean oysters, Ostrea chilensis, in their native Chile (Campalans \& Lohrmann 2009).

The results of this study support other survey work conducted over the past several years that have examined the health and disease status of bivalves in Santa Catarina State (Lima et al. 2001, Da Silva et al. 2002, Sabry 2003, Boehs \& Magalhães 2004, Sabry \& Magalhães 2005, Garcia \& Magalhães 2008, Pontinha 2009, Sabry et al. 2009, Marchiori et al. 2010, Sabry et al. 2011, Da Silva et al. 2012, Ivachuk 2013). This work contributes to baseline health assessments of C. gasar (syn. C. brasiliana), providing first reports of Sphenophrya-like ciliate infections. It has also provided health data on unknown and unidentified parasites or commensal organisms in a range of bivalve species in Brazil, including new reports as for Anomalocardia brasiliana, Crassostrea gasar and Pteria hirundo.

Based on the wild and cultured populations studied here, no OIE-notifiable bivalve diseases were found in the state of Santa Catarina in southern Brazil in the following species: Anomalocardia brasiliana (syn. A. flexuosa), Crassostrea gasar (syn. brasiliana), Nodipecten nodosus and Perna perna. Examination of the wild populations found no OIE-notifiable diseases, suggesting that they may be unlikely to be a harbouring source of disease transmission to cultured populations. Although the current survey did not identify any pathogens or diseases of concern, it provides important baseline health assessment data 
for these species against which any future disease developments or significant changes in population health can be compared. The results of the present study support the Ministry of Fisheries and Aquaculture in Brazil (Ministério da Pesca e Aquicultura - MPA) in the development and implementation of public policies related to aquatic animal health. Currently reference laboratories are being developed for the diagnosis of OIE diseases for molluscs, as part of a National Network of Laboratories of the MPA (Rede Nacional de Laborátorios do Ministério da Pesca e Aquicultura - RENAQUA), which was created in April of 2012 in Brasilia.

Continued monitoring along the Brazilian coast (which would include the development of sampling programs covering broader geographical regions, times of the year, and also be extended to include other bivalve species) would lead to a more comprehensive overview of the health of bivalve populations. This information could then be used to inform managers and producers to enable the environmentally responsible aquaculture development of these economically and socially important species.

\section{ACKNOWLEDGMENTS}

We would like to thank to the Ministry of Fisheries and Aquaculture, Brazil, for the research support provided to the Fundação de Amparo à Pesquisa do Estado de Santa Catarina (FAPESC), Brazil; the National Council of Technological and Scientific Development, Brazil (CNPq-558222/2008-0), for supporting the macro- and microscopical analysis and for providing a grant (CNPq-301072/2007-8); the Coordenação de Aperfeiçoamento de Pessoal de Nível Superior (CAPES), Brazil, for post-doctoral scholarship support for SS; the Pacific Biologic Station and Vancouver Island University (VIU) in Canada for supporting the molecular studies; and the Laboratory for Molluscs Diseases and OIE Reference Laboratory, IFREMER, France, for providing molecular diagnostic protocols and positive control material for the OIE-listed pathogens. We would also like to thank the undergraduate students from Federal University of Santa Catarina (UFSC), Brazil, and Angeline de Bruyns and Nathan Stefani from Vancouver Island University for support in the diagnostic procedure, and the World Fisheries Trust, Canada, for facilitating the partnership between the VIU and the UFSC.

\section{LITERATURE CITED}

Abollo, E., A. Ramilo, S. M. Casas, P. Comesaña, A. Cao, M. J Carballal \& A. Villalba. 2008. First detection of the protozoan parasite Bonamia exitiosa (Haplosporidia) infecting flat oyster Ostrea edulis grown in European waters. Aquaculture 274:201-207.

Araújo, M. L. R. \& C. A. Rocha-Barreira. 2004. Occurrence of Bucephalus sp. (Trematoda: Bucephalidae) in Anomalocardia brasiliana (Gmelin, 1791) (Mollusca: Veneridae) at Canto da Barra Beach, Fortim, Ceará State, Brazil. Arq. Cien. Mar. 37:35-37.

Azevedo, C. \& E. Matos. 1999. Description of Nematopsis mytella n.sp. (Apicomplexa), parasite of the mussel Mytella guyanensis (Mytilidae) from the Amazon Estuary and description of its oocysts. Eur. J. Protistol. 35:427-433.

Azevedo, C., I. Padovan, L. Corral \& P. Padovan. 2005. Ultrastructural description of an unidentified apicomplexan oocyst containing bacteria-like hyperparasites in the gill of Crassostrea rhizophorae. Dis. Aquat. Organ. 65:153-157.

Berthe, F. C. J., F. Roux, R. D. Adlard \& A. Figueras. 2004. Marteiliosis in molluscs: a review. Aquat. Living Resour. 17:433-448.

Boehs, G., T. M. Lenz \& A. Villalba. 2009. Xenomas in Crassostrea rhizophorae (Ostreidae) from Camamu Bay, Bahia, Brazil. Braz. J. Biol. 69:457-458.

Boehs, G. \& A. R. M. Magalhães. 2004. Simbiontes associados com Anomalocardia brasiliana (Gmelin) (Mollusca, Bivalvia, Veneridae) na Ilha de Santa Catarina e região continental adjacente, Santa Catarina, Brasil. Rev. Bras. Zool. 21:865-869.

Boehs, G., A. Villalba, L. O. Ceuta \& J. R. Luz. 2010. Parasites of three commercially exploited bivalve mollusc species of the estuarine region of the Cachoeira river (Ilheus, Bahia, Brazil). J. Invertebr. Pathol. 103:43- 47.

Bower, S. M. 2001. Synopsis of infectious diseases and parasites of commercially exploited shellfish: Ostracoblabe implexa (shell disease) of oysters. Accessed October 2012. Available at: http://www. pac.dfo-mpo.gc.ca/science/species-especes/shellfish-coquillages/ diseases-maladies/pages/oioy-eng.htm.

Bower, S. M., J. Blackbourn \& G. R. Meyer. 1992. Parasite and symbiont fauna of Japanese littlenecks, Tapes philippinarum (Adams and Reeve, 1850), in British Columbia. J. Shellfish Res. 11:13-19.

Brandão, R. P., G. Boehs \& P. M. Da Silva. 2013a. Health assessment of the oyster Crassostrea rhizophorae on the southern coast of Bahia, northeastern Brazil. Rev. Bras. Parasitol. Vet. 22:84-91.
Brandão, R. P., G. Boehs, R. C. Sabry, L. O. Ceuta, M. D. Luz, F. R. Queiroga \& P. M. Da Silva. 2013b. Perkinsus sp. infecting oyster Crassostrea rhizophorae (Guilding, 1828) on the coast of Bahia, Brazil. J. Invertebr. Pathol. 112:138-141.

Bush, A. O., K. D. Lafferty, J. M. Lotz \& A. W. Shostak. 1997. Parasitology meets ecology on its own terms: Margolis et al. revisited. J. Parasitol. 83:575-583.

Campalans, M. \& K. Lohrmann. 2009. Histological survey of four species of cultivated molluscs in Chile susceptible to OIE notifiable diseases. Rev. Biol. Mar. Oceanogr. 44:561-569.

Carrasco, N., A. Villalba, K. B. Andree, M. Y. Engelsma, B. Lacuesta, A. Ramilo, I. Gairín \& M. D. Furones. 2012. Bonamia exitiosa (Haplosporidia) observed infecting the European flat oyster Ostrea edulis cultured on the Spanish Mediterranean coast. J. Invertebr. Pathol. 110:307-313.

Ceuta, L. O. \& G. Boehs. 2012. Parasites of the mangrove mussel Mytella guyanensis (Bivalvia: Mytilidae) in Camamu Bay, Bahia, Brazil. Braz. J. Biol. 72:421-427.

Cochennec, N., F. Le Roux, F. Berthe \& A. Gerard. 2000. Detection of Bonamia ostreae based on small subunit ribosomal probe. $J$. Invertebr. Pathol. 76:26-32.

Corbeil, S., I. Arzul, M. Robert, F. C. J. Berthe, N. Besnard-Cochennec \& M. S. J. Crane. 2006. Molecular characterization of an Australian isolate of Bonamia exitiosa. Dis. Aquat. Organ. 71:81-85.

Costa, R. L. 2007. Prevalência de enfermidades e histopatologia de Perna perna (Mollusca) em Florianópolis/SC, Brasil. Master degree dissertation, Federal University of Santa Catarina, Florianópolis, Brazil.

Da Silva, P. M., F. Cremonte, R. C. Sabry, R. D. Rosa, L. Cantelli \& M. A. Barracco. 2009. Presence and histopathological effects of the Parvatrema sp. (Digenea, Gymnophallidae) in the stout razor clam Tagelus plebeius (Bivalvia, Psammobiidae). J. Invertebr. Pathol. 102:14-20.

Da Silva, P. M., A. R. M. Magalhães \& M. A. Barracco. 2002. Effects of Bucephalus sp. (Trematoda: Bucephalidae) on Perna perna mussels from a culture station in Ratones Grande Island, Brazil. J. Invertebr. Pathol. 79:154-162.

Da Silva, P. M., A. R. M. Magalhães \& M. A. Barracco. 2012. Pathologies in commercial bivalve species from Santa Catarina State, southern Brazil. J. Mar. Biol. Ass. U.K. 92:571-579.

Da Silva, P. M., M. P. Scardua, R. T. Vianna, R. C. Mendonça, C. B. Vieira, C. F. Dungan, G. P. Scott \& K. S. Reece. 2014. Two Perkinsus spp. infect Crassostrea gasar oysters from cultured and 
wild populations of the Rio São Francisco Estuary, Sergipe, northeastern Brazil. J. Invertebr. Pathol. 119:62-71.

Da Silva, P. M., M. P. Scardua, C. B. Vieira, A. C. Alves \& C. F. Dungan. 2015. Survey of pathologies in Crassostrea gasar (Adanson, 1757) oysters from cultured and wild populations in the São Francisco Estuary, Sergipe, northeast Brazil. J. Shellfish Res. 34:289-296.

Da Silva, P. M., R. T. Viannab, C. Guertler, L. P. Ferreira, L. N. Santana, S. Fernández-Boo, A. Ramilo, A. Cao \& A. Villalba. 2013. First report of the protozoan parasite Perkinsus marinus in South America, infecting mangrove oysters Crassostrea rhizophorae from the Paraíba River (NE, Brazil). J. Invertebr. Pathol. 113:96-103.

De Vico, G. \& F. Carella. 2012. Morphological features of the inflammatory response in molluscs. Res. Vet. Sci. 93:1109-1115.

Dinamani, P., P. M. Hine \& J. B. Jones. 1987. Occurrence and characteristics of the haemocyte parasite Bonamia sp. in the New Zealand dredge oyster Tiostrea lutaria. Dis. Aquat. Organ. 3:37-44.

Doonan, I. J., H. J. Cranfield \& K. P. Michael. 1994. Catastrophic reduction of the oyster, Tiostrea chilensis (Bivalvia: Ostreidae), in Foveaux strait, New Zealand, due to infestation by the protistan Bonamia sp. N. Z. J. Mar. Freshw. Res. 28:335-344.

Dungan, C. F., R. B. Carnegie, K. M. Hill, C. B. McCollough, S. E. Laramore, C. J. Kelly, N. A. Stokes \& J. Scarpa. 2012. Diseases of oysters Crassostrea ariakensis and C. virginica reared in ambient waters from the Choptank River, Maryland and the Indian River Lagoon, Florida. Dis. Aquat. Organ. 101:173-183.

EPAGRI. 2014. Síntese informativa da maricultura 2014. Florianopolis, Brazil: EPAGRI Empresa de Pesquisa Agropecuária e Extensão Rural de Santa Catarina. Assessed April 2016. Available at: http://www.epagri.sc.gov.br/wp-content/uploads/2013/08/Sintese_ informativa_da_maricultura_2014.pdf.

FAO. 2004. National Aquaculture Sector Overview. Brazil. Rome, Italy: FAO Fisheries and Aquaculture Department. Assessed October 2012. Available at: http://www.fao.org/fishery/countrysector/naso_brazil/en.

Ferreira, L. P., R. C. Sabry, P. M. da Silva, T. C. V. Gesteira, L. de Souza Romão, M. P. Paz, R. G. Feijoì, M. P. D. Neto \& R. Maggioni. 2015. First report of Perkinsus beihaiensis in wild clams Anomalocardia brasiliana (Bivalvia: Veneridae) in Brazil. Exp. Parasitol. 150:67-70.

Galvão, M. S. N., M. B. Henriques, O. M. Pereira \& H. L. A. Marques. 2006. Ciclo reprodutivo e infestação parasitária de mexilhões Perna perna (Linnaeus, 1758). B Inst Pesca 32:59-71.

Garcia, P. \& A. R. M. Magalhães. 2008. Protocolo de identificação e quantificação de bucefalose (enfermidade laranja) em mexilhões Perna perna. B Inst Pesca 34:11-19.

Hill, K. M., R. B. Carnegie, N. Aloui-Bejaoui, R. E. Gharsalli, D. M. White, N. A. Stokes \& E. M. Burreson. 2010. Observation of a Bonamia sp. infecting the oyster Ostrea stentina in Tunisia, and a consideration of its phylogenetic affinities. J. Invertebr. Pathol. 103:179-185.

Hine, P. M. 1996. The ecology of Bonamia and decline of bivalve molluscs. N. Z. J. Ecol. 20:109-116.

Hine, P. M. \& J. B. Jones. 1994. Bonamia and other aquatic parasites of importance to New Zealand. N. Z. J. Zool. 21:49-56.

Howard, D. W., E. J. Lewis, B. J. Keller \& C. S. Smith. 2004. Histological techniques for marine bivalve molluscs and crustaceans. NOAA Technical Memorandum NOS NCCOS5. Oxford, MD: Oxford Lab., National Marine Fisheries Serv. 218 pp.

Howard, D. W. \& C. S. Smith. 1983. Histological techniques for marine bivalve mollusks. NOAA Technical Memorandum NMFS-F/NEC-25. Woods Hole, MA: Oxford Lab., National Marine Fisheries Serv. 97 pp.

Ivachuck, C. S. 2012. Sobrevivência e aspectos imunológicos da ostra Crassostrea gigas (Thunberg, 1793): efeito do manejo de cultivo. Master degree dissertation, Federal University of Santa Catarina, Florianópolis, Brazil.

Kinne, O. 1983. Diseases of marine animals. Volume II. Introduction, Bivalvia to Scaphopoda. Hamburg, Germany: Biologische Anstalt Helgoland. pp. 477-879.
Kroeck, M. A. 2010. Gross signs and histopathology of Ostrea puelchana infected by a Bonamia exitiosa-like parasite (Haplosporidia). Dis. Aquat. Organ. 89:229-236.

Kroeck, M. A. \& J. Montes. 2005. Occurrence of the haemocyte parasite Bonamia sp. in flat oysters Ostrea puelchana farmed in San Antonio Bay (Argentina). Dis. Aquat. Organ. 63:231-235.

Lauckner, G. 1983. Diseases of mollusca: Bivalvia. In: Kinne, O., editor. Diseases of marine animals: introduction, Bivalvia to Scaphopoda. Hamburg, Germany: Biologische Anstalt Helgoland. pp. 477-961.

Le Roux, F., G. Lorenzo, P. Peyret, C. Audemard, A. Figueras, C. Vivares, M. Gouy \& F. C. J. Berthe. 2001. Molecular evidence for the existence of two species of Marteilia in Europe. J. Eukaryot. Microbiol. 48:449-454.

Lima, F. C., M. G. Abreu \& E. F. M. Mesquita. 2001. Monitoramento histopatológico de mexilhão Perna perna da Lagoa de Itaipu, Niterói, RJ. Arq. Bras. Med. Vet. Zootec. 53:203-206.

Magalhães, A. R. M. 1998. Efeito da parasitose por Trematoda Bucephalidae na reprodução, composição bioquímica e índice de condição de mexilhões Perna perna (L.). PhD thesis, Federal University of Santa Catarina, Florianópolis, Brazil.

Magalhães, A. R. M. \& J. F. Ferreira. 2006. Patologias e manejo em malacocultura. In: Siva-Souza, A. T., editor. Sanidade de organismos aquáticos no Brasil. Abrapoa, Maringá, Brazil.

Marchiori, N. C., A. R. M. Magalhaes \& J. J. Pereira. 2010. The life cycle of Bucephalus margaritae Ozaki \& Ishibashi, 1934 (Digenea, Bucephalidae) from the coast of Santa Catarina State, Brazil. Acta Scientiarum 32:71-78.

Matos, E., P. Matos \& C. Azevedo. 2005. Observations on the intracytoplasmic microsporidian Steinhausia mytilovum, a parasite of mussel (Mytella guyanensis) oocytes from the Amazon River estuary. Braz. J. Morphol. Sci. 22:183-186.

Medeiros, S. C. 2013. Bucefalose no cultivo de mexilhões: relação do parasita com os hospedeiros iniciais. Master degree dissertation, Federal University of Santa Catarina, Florianópolis, Brazil.

Narchi, W. 1966. Encontro de Bucephalopsis haimeana (Lacaze-Duthiers) no Brasil. Cienc. Cult. 18:22-24.

Nascimento, I. A., D. H. Smith, L. F. Kern \& S. A. Pereira. 1986. Pathological findings in Crassostrea rhizophorae from Todos os Santos Bay, Bahia, Brazil. J. Invertebr. Pathol. 47:340-349.

OIE. 2011. Manual of diagnostic tests for aquatic animals 2011. World Organization of Animal Health. Accessed October 2012. Available at: http://www.oie.int/international-standard-setting/aquatic-manual/ access-online/.

Oliveira, J. B. 2008. Parasitos associados com a lambreta Lucina pectinata (Gmelin, 1791) (Mollusca: Bivalvia) na região estuarina do Rio Cachoeira (Ilhéus, Bahia). Graduation degree, UESC, Ilhéus, Brazil.

Padovan, I. P., L. Corral, L. A. Tavares, P. A. Padovan \& C. Azevedo. 2003. Fine structure of the oocyst of Nematopsis mytella (Apicomplexa, Porosporidae), a parasite of the mussel Mytella falcate and of the oyster Crassostrea rhizophorae (Mollusca, Bivalvia) from the northeastern Atlantic Coast of Brazil. Braz. J. Morphol. Sci. 20:141-145.

Pinto, T. R. \& G. Boehs. 2008. Nematopsis sp. (Apicomplexa: Eugregarinida) em Mytella guyanensis (Lamarck, 1819) (Bivalvia: Mytilidae) da região estuarina do Rio Cachoeira, Ilhéus, Bahia, Brasil. Braz. J. Vet. Res. Anim. Sci. 45:95-100.

Poli, C. R. 2004. Cultivo de ostras do Pacífico (Crassostrea gigas). In: Poli, C. R., A. T. B. Poli, E. Andreatta \& E. Beltrame, editors. Aquicultura: experiências brasileiras. Florianópolis, Brazil: Multitarefa. pp. 251-266.

Pontinha, V. A. 2009. Diagnóstico da saúde da ostra Crassostrea gigas (Thunberg, 1793) cultivada em Florianopólis/SC. Master degree dissertation, Federal University of Santa Catarina, Florianópolis, Brazil.

Queiroga, F. R., L. F. Marques-Santos, H. Hégaret, P. Soudant, N. D. Farias, A. D. Schlindwein \& M. P. da Silva. 2013. Immunological responses of the mangrove oysters Crassostrea gasar naturally infected by Perkinsus sp. in the Mamanguape Estuary, Paraíba State (northeastern, Brazil). Fish Shellfish Immunol. 35:319-327. 
Queiroga, F. R., R. T. Vianna, C. B. Vieira, N. D. Farias \& P. M. da Silva. 2015. Parasites infecting the cultured oyster Crassostrea gasar (Adanson, 1757) in northeast Brazil. Parasitology 142(6):756-766.

Ray, S. M. 1954. Biological studies of Dermocystidium marinum, a fungus parasite of oysters. Rice Institute pamphlet (Monogr Biol Spec Ser Iss). Washington, DC: Rice Institute.

Ray, S. M. 1966. A review of the culture method of detecting Dermocystidium marinum with suggested modifications and precautions. Proc. Natl. Shellfish. Assoc. 54:55-69.

Sabry, R. C. 2003. Parasitas em ostras de cultivo (Crassostrea rhizophorae e Crassostrea gigas) da Ponta do Sambaqui, Florianópolis, SC. Master degree dissertation, Federal University of Santa Catarina, Florianópolis, Brazil.

Sabry, R., P. M. Da Silva, G. T. C. Vasconcelos, V. A. Pontinha \& A. R. M. Magalhães. 2011. Pathological study of oysters Crassostrea gigas from culture and C. rhizophorae from natural stock of Santa Catarina Island, SC, Brazil. Aquaculture 60:43-50.

Sabry, R. C., T. C. V. Gesteira \& G. Boehs. 2007. First record of parasitism in the mangrove oyster Crassostrea rhizophorae (Bivalvia: Ostreidae) at Jaguaribe River estuary-Ceará, Brazil. Braz. J. Biol. 67:755-758.

Sabry, R. C., T. C. Gesteira, A. R. M. Magalhães, M. A. Barracco, C. Guertler, L. P. Ferreira, R. T. Vianna \& P. M. Da Silva. 2013. Parasitological survey of mangrove oyster, Crassostrea rhizophorae, in the Pacoti River Estuary, Ceará State, Brazil. J. Invertebr. Pathol. 112:24-32.

Sabry, R. C. \& A. R. M. Magalhães. 2005. Parasitas em ostras de cultivo (Crassostrea rhizophorae e Crassostrea gigas) da Ponta do Sambaqui, Florianópolis, SC. Arq. Bras. Med. Vet. Zootec. 57:194-203.
Sabry, R. C., R. D. Rosa, A. R. M. Magalhaes, M. A. Barracco, T. C. V. Gesteira \& P. M. da Silva. 2009. First report of Perkinsus sp. infecting mangrove oysters Crassostrea rhizophorae from the Brazilian coast. Dis. Aquat. Organ. 88:13-23.

Shaw, B. L. \& H. I. Battle. 1957. The gross and microscopic anatomy of the digestive tract of the oyster Crassostrea virginica (Gmelin). Can. J. Zool. 35:325-347.

Shelley C. C., J. S. Glazebrook, E. Turak, L. Winsor \& G. R. W. Denton. 1988. Trematode (Digenea:Bucephalidae) infection in the burrowing clam Tridacna crocea from the Great Barrier Reef. Dis Aquat Org 4:143-147.

Suárez-Morales, E., M. P. Scardua \& P. M. Da Silva. 2010. Occurrence and histopathological effects of Monstrilla sp. (Copepoda: Monstrilloida) and other parasites in the brown mussel Perna perna from Brazil. J. Mar. Biol. Ass. U.K. 90:953-958.

Sühnel, S., C. S. Ivachuk, A. L. C. Schaefer, V. A. Pontinha, M. L. Martins, A. Figueras, G. R. Meyer, S. R. M. Jones, J. C. Stewart, H. J. Gurney-Smith, A. R. M. Magalhães \& S. M. Bower. 2014. Detection of a parasitic amoeba (order Dactylopodida) in the female gonad of oysters in Brazil. Dis. Aquat. Organ. 109:241-250.

Umiji, S., J. E. Lunetta \& R. M. V. Leonel. 1976. Infestation of the mussel Perna perna by digenetic trematodes of the Bucephalidae family, gen. Bucephalus. An. Acad. Bras. Cienc. 47:115-117.

Zeidan, G. C., M. S. A. Luz \& G. Boehs. 2012. Parasites of economically important bivalves from the southern coast of Bahia State, Brazil. Rev. Bras. Parasitol. Vet. 21:391-398. 